DOI: $10.19195 / 0137-1169.37 .1$

\title{
The concept of HOME in Polish and Portuguese - distant cultures, similar concepts
}

\section{Introduction}

What are the universal and the culture-specific aspects concerning 'a place people live'? Apart from having very different material forms, people's homes do have many things in common (like belonging, family, shelter, emotional warmth and security). But as different cultures put the emphasis on different aspects of 'living with other people', accordingly concepts like home, privacy or family vary (cf. Rapoport 1969).

I think that investigating the notion of HOME is of crucial importance now. It is a very fluid concept in the world of today (cf. Bauman 2011). We can observe a decline of the community, of traditional family, and the relations among people and between people and places are changing rapidly (Brydon 2007). That is why, here I would like to "address [above all - Z.B.S.] the emotional salience of home" (cf. Gurney 1997:383) in two distant European languages, Polish and Portuguese. "An overused aphorism in making sense of home is that it is where the heart is. Despite this the significance of love, happiness, anger, depression, and loss has remained largely unacknowledged in contemporary writing on home. It seems clear then that any new research agenda must address the emotional salience of home" (Gurney 1997:383).

Working within the EUROJOS research project "Linguistic and cultural worldview of the Slavic people and their neighbors" (2009-2015, affiliated with the Department of Slavic Studies, Polish Academy of Science, Warsaw, see: www.ispan. waw.pl) I published a bunch of texts on the concept of home in European Portuguese (Bułat Silva 2012a, b, 2014a, b, 2015), also in contrast with its Spanish equivalent (Bułat Silva/Stępien 2014). Here I would like to compare the worldviews on home in Polish and in Portuguese. My preliminary hypothesis is that, in spite of a great geographical and linguistic distance, the two cultures have many things in common. 
The paper will be organized as follows. Firstly, I will sketch briefly the methodology I use here, that is the Natural Semantic Metalanguage (Wierzbicka 1996, Goddard/Wierzbicka 2002). Next, I will check at the dictionary definitions of the word dom, go through its different meanings and see how they are interrelated. Then, I will examine idiomatic expressions and proverbs with dom, and on the basis of the above lexical data I will delineate its metasemantic explication. Having described the linguistic picture of dom, I will proceed to examine its Portuguese counterpart, casa in much the same way. On the basis of dictionary definitions and idioms, I will build a radial network of the lexeme casa and then its metasemantic explication. That will enable me to compare the meaning each lexeme has respectively in Polish and in Portuguese and see whether my preliminary hypothesis is justified.

\section{Methodology: Natural Semantic Metalanguage}

NSM, 'natural semantic metalanguage' (Wierzbicka 1996, Goddard/Wierzbicka 2014) is a decompositional approach to semantics. Within this method, the meaning of a given word is explicated by means of a small set of universal words and a corresponding mini-grammar (and the resulting paraphrase is called metasemantic explication). The NSM is based on two assumptions: that 1) every language has an irreducible semantic core, and that 2) the irreducible cores of all natural languages match, thus forming the irreducible core of all languages that enable us to explore different ways of thinking encoded in different languages of the world (Wierzbicka 2010:17). This is not an easygoing claim, but the presence of the semantic core has been tested empirically in languages belonging to quite a few different language families in the world (Goddard/Wierzbicka 2002).

The set of universal semantic primitives or primes consists of 65 lexical units (and a lexical unit is defined as a pairing of a single specifiable meaning with a lexical form, Goddard 2001:2). The minilanguage includes among others deictics I, YOU, NOW and HERE, mental predicates THINK, WANT and FEEL, evaluators GOOD and BAD and logical concepts such as NOT, IF and BECAUSE (cf. Table 1).

Table 1: NSM - a list of semantic primitives grouped into 12 related categories

1. I, YOU, SOMEONE, SOMETHING/THING, PEOPLE, BODY, KIND, PART

2. THIS, THE SAME, OTHER

3. ONE, TWO, MUCH/MANY, LITTLE/FEW, SOME, ALL

4. GOOD, BAD, BIG, SMALL

5. THINK, KNOW, WANT, DON'T WANT, FEEL, SEE, HEAR

6. SAY, WORDS, TRUE

7. DO, HAPPEN, MOVE

8. BE (SOMEWHERE), THERE IS, BE (SOMEONE/SOMETHING), (IS) MINE

9. LIVE, DIE

10. WHEN/TIME, NOW, BEFORE, AFTER, A LONG TIME, A SHORT TIME, FOR SOME TIME, MOMENT 
11. WHERE/PLACE, HERE, ABOVE, BELOW, FAR, NEAR, SIDE, INSIDE, TOUCH

12. NOT, MAYBE, CAN, BECAUSE, IF, VERY, MORE, LIKE

Source: Wierzbicka (2016:31).

It is assumed that the primes are intuitively intelligible to all people in the world. Thus the metalinguistic explication aims to be free from ethnocentric bias and culturally transparent (although not easy at all when it comes to understanding it). We may say that the NSM allows us to describe fairly complicated and culturally bound concepts without relying on Anglo categories, such as, for example, home, privacy or emotion, and, what is really important for the present paper, provides a clear tertium comparationis to compare similar yet not the same notions (like that of home) in different languages. The NSM explication is based on a naive picture of the reality (Apresjan 1994), it does not aim to describe a given concept from a scientific point of view, but rather points towards presenting a viewpoint of an ordinary man. It is this premise that brings the NSM close to the Polish Ethnolinguistic School of Lublin, with its idea of "językowy obraz świata" ('linguistic worldview') (JOS), described as "a language-entrenched interpretation of reality, which can be expressed in the form of judgments about the world, people, things or events" (Bartmiński 2009:23).

\section{Polish dom}

\subsection{Lexicographic data}

Let us take a look at the dictionary definitions of the word dom. Polish dictionaries (Dubisz 2006, PWN online) postulate about seven or eight meanings of dom, that may be organized in the following fashion (Fig. 1):

(1.1.4.1) one's own place

(1.1.4) flat

(1.1.3) expenses

(1.1.2) furniture $\leftarrow$

(1.1.1) family $\leftarrow$

(1.1.1.1) dynasty

Figure 1: Radial network of dom
(1.1.4.2) place where a board game starts

\section{(1) building}

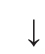

(1.1) private house

(1.2) public service

(1.3) company 
It seems that the centre of this radial network is the most general meaning of dom, namely (1) 'building'. This meaning may be restricted in three different ways: as a (1.1) 'private, single-family house', as a (1.2) 'public service' (e.g. dom dziecka 'orphanage', dom kultury 'youth centre', dom poprawczy 'youth rehabilitation centre', Dom Boży 'temple'), and as a (1.3) 'company' (e.g. dom towarowy 'shopping mall', dom maklerski 'brokerage centre', dom pogrzebowy 'funeral house'). The metonymy-based instantiation relates the meaning (1.1) 'private house', with: (1.1.1) 'family', that is 'people living together in the house' (that can be further instantiated as a (1.1.1.1) 'royal family' or 'dynasty'), and also with (1.1.2) 'furniture', 'lifelong belongings', or in other words 'all the things that are inside the house' (as in the example Spakowali caty dom i wyjechali do USA 'They packed the whole house and went to the USA'), with (1.1.3) 'home expenses' ${ }^{1}$ (as in Moja pensja idzie cała na dom i jedzenie, 'All the money I earn I spend on home and food'), and with (1.1.4) 'flat' or 'a place to live'. This last meaning serves as a base for two metaphorical extensions: (1.1.4.1) 'one's own place' ${ }^{2}$ and (1.1.4.2) 'a place where a board game starts' ${ }^{3}$

\subsection{Genera proxima}

In European languages, it seems, the concept of HOME can belong to three different domains, genera proxima. It can be seen as 1) a PLACE, where people live, as 2) PEOPLE who inhabit this place and are connected through the network of emotional and social relationships, and as 3) a THING, often valuable, that should be purchased and then taken care of (see also Bułat Silva 2012a, b). The above is also true for Polish. Figure 2 shows how different meanings of dom may be organized as far as their genera proxima are concerned. It may also be seen that as the result of the perspective that we take, and that Bartmiński (2009:19) calls linguistic viewpoint - some of the meanings overlap. E.g. we may treat 'flat' as a PLACE or a THING that must be purchased on loan, and when we talk about 'institution', or 'public service', we may either refer to 'PEOPLE who work for this institution' or 'PLACE where the institution is located'.

\footnotetext{
${ }^{1}$ It should be noted here that the dictionaries don't treat the two above meanings as separate. I postulate to separate (1.1.2) from (1.1.3) on the basis of lexical data. When we consider the sentences (1.1.2) Spakowali caty dom $i$ wyjechali do USA. 'They packed the whole house and went to the USA'), and (1.1.3) Moja pensja idzie cała na dom i jedzenie, 'All the money I earn I spend on home and food', we can clearly see that in the first one, (1.1.2) 'home' may be substituted by 'belongings' or 'possessions', whereas in the other one it is rather paraphrased as 'gas or electricity bills' .

2 This meaning is not acknowledged by the dictionaries either.

3 Of all the Slavic languages, this meaning exists only in Polish (Zaśko-Zielińska 1997:50).
} 


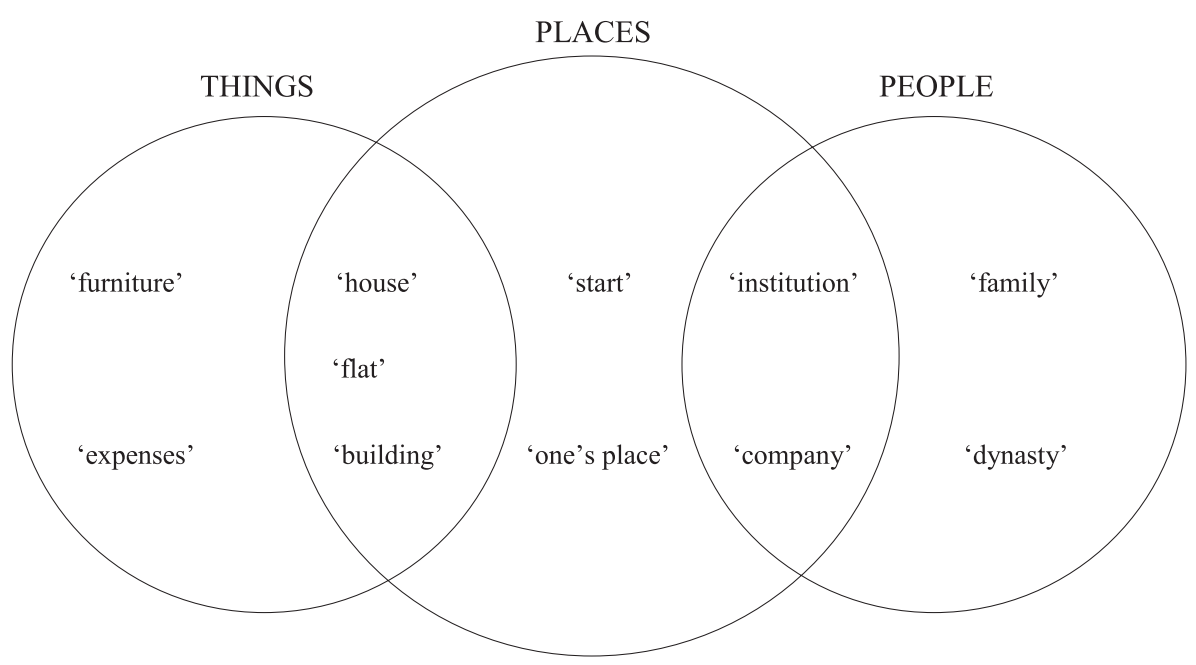

Figure 2: Genera proxima of dom

\subsection{Dom as a cultural value: synonyms, idioms and proverbs}

Bartmiński claims that "[t]he cultural model of the 'Polish home' $[\ldots]$ took its shape in the nineteenth century when Poland did not exist as an independent state (1795-1918)", and that "[dom - Z.B.S.] in Poland is the 'stronghold' of national identity" (Bartmiński 2009:149). I would rather say that dom used to be "the 'stronghold' of national identity". The profound social and economic changes in Poland in the past two or three decades and the advancing globalization have done away with all the patriotic connotations dom once had. Young people in Poland no longer see the relationship between their homes and patriotism (Żywicka 2006).

When we think of dom as an important cultural value, its two basic meanings come into mind. It is of course 'a place where people live' and 'people who live together', or in other words 'home' and 'family' - that according to Bartmiński (2009:157) form a semantic gestalt. That social characteristic of the Polish dom is emphasized by many researchers (Dobraczyński 2011, Maćkiewicz 1997, Zaśko-Zielińska 1997, Żywicka 2006).

Let us examine now the synonyms of dom in those two interrelated meanings. There is dach nad glowa 'roof over one's head', that uses the iconic metonymy to picture an essential feature of dom, namely 'being a shelter'. There is an expression rodzinne progi 'family doorsteps', that pictures dom as something one 'enters'. There are wtasny kat 'one's own corner' and cztery katy 'four corners', that emphasize that dom is 'a place that belongs to someone', and that it is usually rectangular and closed. An important, although slightly archaic synonym is ognisko domowe 'hearth', that places the fireplace, source of light, food, and warmth in the centre of 
Polish home. Also archaic is the word pielesze - in the past pielesz meant something as 'lair' or 'hideout' - that underlines that dom is a place where people rest and sleep.

Checking the idiomatic expressions with $d o m$, we may see that once again dom is pictured as a safe place, a place where you can do what you want: czuć sie jak u siebie $w$ domu 'to feel like at home', means 'to feel safe and confident'; jestem $w$ doтu, lit. 'I am at home', is 'now, I understand'. Dom is also related to some responsibilities and duties: mieć caly dom na głowie, lit. 'to have the whole home on one's head', is 'to take care of all the family and housework matters'. Another idiom, mieć nie wszystkich $w$ domu, lit. 'not to have everybody in the house', meaning 'to go crazy', evokes the picture of dom as a harmonic whole: when one member is missing, things go wrong.

From the analysis of the Polish proverbs relating to dom, some other characteristics may be drawn. The saying Chtodno, głodno i do domu daleko 'We are cold, hungry and far from home', as Bartmiński (2009:152) rightly notices, 'evokes two basic functions of DOM: to provide food and warmth'. This characteristic of dom is corroborated by its above mentioned synonym, ognisko domowe 'hearth' or 'domestic fireplace', where 'fireplace', that is the source of light and warmth, is used metonymically to name a human dwelling. But the food is not enough to feel at home, Lepszy w domu groch, kapusta, niż na wojnie kura tlusta 'Better to have peas and cabbage at home, than a fat hen at war', as the other proverb goes. Once again, the security and shelter provided by dom are more important.

Another feature of dom is the famous Polish hospitality: Gość w dom, Bóg $w$ dom 'Guest into the house, God into the house'. That value is reaffirmed by some idiomatic expressions: petnic honory domu 'to do the honors of the house', 'to receive guests (usually not being the person who was supposed to do it)', and prowadzić dom otwarty, lit. 'to run an open house', meaning 'to receive many guests'. Być gościem $w$ domu 'be a guest in a house', is a slightly negative expression used when someone does not participate in family life, and refuses to do his chores. That idiom emphasizes that guests are treated in a different manner than family members; yet, they shouldn't take advantage of it: Kiedy jesteś w cudzym domu, nie zawadzajże nikomu 'When in other man's house, do not bother anyone'. Nevertheless, Wszędzie dobrze, ale $w$ domu najlepiej 'There is no place like home', because Kazdy jest panem we wtasnym domu, literally 'Everyone is a lord in his own house', he can do what he wants to do, or, as the other saying goes, Wolnoć Tomku w swoim domku, lit. 'you are free to do as you like, Thomas, in your own little house', all the three expressions stressing the privacy and freedom dom should provide.

\subsection{NSM definition of dom}

Bartmiński (2009:157) claims that three categories on which the concept dom is built, namely BUILDING, PLACE TO LIVE and FAMILY are combined into 
a semantic gestalt [A FAMILY LIVES IN A BUILDING]. Yet, as Zaśko-Zielińska (1997:47) rightly points out, "the meaning of the word dom does not consist of only two features: building and people living there". Her example Dom to nie hotel 'Dom is not a hotel'4, clearly shows that it is not enough to say 'It is her dom, because she lives there (with a family)'. Certainly, the feelings of security, warmth, acceptance, and love are important, maybe even more important than the physical aspect of the place we call dom. There is one more factor - usually ignored by the linguists who investigate the notion of home in different languages that matters in the linguistic picture of home. It is a factor of TIME; to call a place home one should live there 'for a long time', not 'for a short time'.

In my opinion, the most important semantic elements needed to describe the concept dom are the ones named by Bartmiński (2009:157): PLACE, PEOPLE, LIVE, but also, BODY and DO, showing the physical aspect of dom. I would also add FEEL, THINK, WANT and GOOD that reveal that dom is an important cultural value, and is related to feelings, especially 'good feelings'.

dom

a) a place of one kind,

b) someone can live in this place with some other people for a long time,

c) if someone lives in a place of this kind, this someone can think about this place like this:

d) when I am in this place, I can often feel something good in my body,

e) when I am in this place, nothing bad can happen to me,

f) when I am in this place, if I want to do something, I can do it,

g) this place is not like any other places,

h) I cannot feel like this in any other places,

i) when this someone thinks like this, this someone can feel something good because of this,

j) if someone lives in a place of this kind with some other people, often it is like this:

k) this someone wants to do good things for these people,

l) this someone wants to be with these people in this place for some time,

$\mathrm{m})$ this someone wants to do some things with these people for some time,

n) all these people are like parts of one something,

o) because of this, all these people often can feel something good,

p) if someone lives in a place of this kind, often this someone can think like this:

q) when some other people are in this place for some time,

r) I want to do good things for these other people when they are here,

s) not like the things I do in other places,

t) because of this, these other people can feel something good,

u) it is good if someone can think like this about a place

${ }^{4}$ Dom to nie hotel is a Polish saying, kind of a reprimand, that may be used when one family member comes home only to sleep and eat, and does not participate in family life (does not talk much to other members of the family, and does not do housework, shopping etc.). 
Polish dom is not an institution, nor a thing to be purchased, it is primarily 'a place of one kind' where someone 'can live with some other people' $(a-b)$. Now these first lines seem to capture well that dom is 'ones's own place' ('someone can live here'), and at the same time it is a place of living together 'with some other people'. As it was said before, the time scope is also important, since at dom people live 'for a long time', not 'for a short time'. Now, next few lines are about thoughts and feelings people can have about dom: when they are at dom, they can often feel warm and cosy there - hence the prime BODY in line d). They know they are safe in this place ('nothing bad can happen to me', line e). They can express themselves freely, without any constraints that a society imposes on them in public places - if they want to do something, they can do it (f). Lines g) and h) refer to 'uniqueness' attributed to dom in Polish imaginary - 'there is no place like dom'. All these thoughts about dom being one's own private place and a secure and warm shelter give way to good feelings the person thinking of dom may experience (i).

For the Polish, dom is intrinsically connected to the family, where people love each other, help each other and like spending time together $(k-m)$. They are all like 'parts of one thing' ${ }^{5}$ (n), and thanks to all the things they do together, they often feel happy (o). That sense of community and belonging is very important to the Polish notion of 'home'. Next part of the definition tries to capture the so-called Polish hospitality $(\mathrm{p}-\mathrm{t})$. Polish do treat other people in a very different manner when they are at home and when they are in public space: 'I want to do good things for these other people when they are here, not like the things I do in other places' $(r-s)$. When your friend brings someone to your dom, you will try to give him the shirt off your back, and make everything to make him feel well - a guest cannot feel bad at your home $(\mathrm{t})$. In the last line $(\mathrm{u})$, the great value ascribed to dom in the Polish culture is shown. The very fact of having dom make people feel well.

\section{Portuguese $c a s a^{6}$}

\subsection{Lexicographic data}

At the very first glance, what strikes us most when we look at the dictionary definitions of casa is a much larger number of different meanings this Portuguese word has in comparison with its Polish equivalent, dom. These meanings may be organized as follows (Fig. 3):

5 Concepts like "family" and "friends" are also social but the central ideas behind them are not those of "doing something for one another" or "doing something with one another", but rather, those of "being parts of one whole" or "being like parts of one whole" (Wierzbicka 2009:159).

${ }^{6}$ As for the Portuguese casa, I briefly summarize here what I wrote in my article "O conceito de casa em português europeu" devoted solely to the notion of 'home' in Portuguese (Bułat Silva 2012a, see also Bułat Silva 2012b, 2015). 


$\begin{array}{ll}\rightarrow & (1.1 .5 .2 .6) \text { buttonhole } \\ \rightarrow & (1.1 .5 .2 .5) \text { decade } \\ \rightarrow & (1.1 .5 .2 .4) \text { place value (in mathematics) } \\ \rightarrow & (1.1 .5 .2 .3) \text { cell in a honeycomb } \\ \rightarrow & (1.1 .5 .2 .2) \text { square on a board or a box in a table }\end{array}$

(1.1.5.2) room $\quad(1.1 .5 .1)$ 'one's own place'

$\begin{array}{llllll} & \leftarrow & \rightarrow & & \\ (1.1 .5) & \text { flat } & \leftarrow & & \\ (1.1 .4) & \text { rural estate } & \leftarrow & \text { (1) building } & \\ (1.1 .3) & \text { expenses } & \leftarrow & & \\ (1.1 .2) & \text { furniture } & \leftarrow & (1.1) \text { private house } & \text { (1.2) public service }(1.3) \text { company } \\ (1.1 .1) & \text { family } & \leftarrow & & \downarrow \\ \downarrow & & \downarrow & & \downarrow\end{array}$

(1.1.1.1) dynasty (1.1.1.2) team who help the Head of State

(1.3.1) restaurant

Figure 3: Radial network of casa

Again, the central, most general meaning is (1.) 'building'. This meaning is instantiated as (1.1) 'private house', (1.2) 'public service' (as in Casa da Moeda 'mint', Casa da Câmara, Town Hall, casa de correcção 'youth rehabilitation centre'), and as a (1.3) 'company' (e.g. casa comercial, 'shopping mall', casa bancária 'bank'). The last meaning can be further instantiated as a (1.3.1) 'restaurant'. (The dictionaries do not postulate the latter, nonetheless I believe it is a separate meaning, inasmuch as there are so many linguistic expressions where casa means simply 'a place where people eat and drink'. There is casa típica, literally 'typical house' or casa de fados 'house of fado', both meaning a 'restaurant where fado is sung'; casa de chá 'tea house', casa de comes e bebes 'house of food and drink', and casa de pasto cheap restaurant'). Several meanings may be said to be metonymy-based. Just as in the case of Polish dom, there is (1.1.1) 'family', that can be further instantiated as (1.1.1.1) 'dynasty' and as (1.1.1.2) 'team who help the Head of State'; there is (1.1.2) 'furniture', 'belongings'; (1.1.3) 'expenses' (O ordenado vai todo para a alimentação, casa e vestuário 'His salary goes for food, home and clothes'); (1.1.4) 'rural estate', and (1.1.5) 'flat'. This last meaning gives way to a metaphorical ex-

\footnotetext{
7 In the "Dictionary of Old Polish" this meaning is ascribed also to the Polish dom (Zaśko-Zielińska 1997:44).
} 
tension (1.1.5.1) 'one's own place ${ }^{8}$ and one more, metonymy-based meaning, typical for Portuguese - and absent from, for example, Spanish - (1.1.5.2) 'room' (as in casa de banho 'bathroom', or in a sentence A cozinha era uma casa espaçosa com varanda sobre o rio 'The kitchen was a big room with a balcony over the river'). This last meaning is a base for several other meanings, metaphorical extensions of (1.1.5.2): (1.1.5.2.1) 'each one of the twelve sections that the sky is divided into (zodiac)' ' (1.1.5.2.2) 'square on a board or a box in a table' (as in casa pretas e casa brancas 'black and white squares' e.g. on a chessboard); (1.1.5.2.3) 'cell in a honeycomb'; (1.1.5.2.4) 'place value in mathematics' (as in casa das unidades 'ones place'); (1.1.5.2.5) 'decade', especially when talking about someone's age (e.g. $E$ um homem ainda novo, ai na casa dos quarenta 'He is still a young man, he is in his forties'); and (1.1.5.2.6) 'buttonhole', as in a sentence Na carcela do casaco fez casas para cinco botões 'He made five buttonholes in a lap of his coat'.

\subsection{Genera proxima}

Now, when we compare the hypernyms of different meanings of casa with the hypernyms of dom, we may easily notice that for casa there are more meanings belonging to a category PLACES, with even one meaning that extends that category towards the domain of $\operatorname{TIME}^{10}$ (Fig. 4).

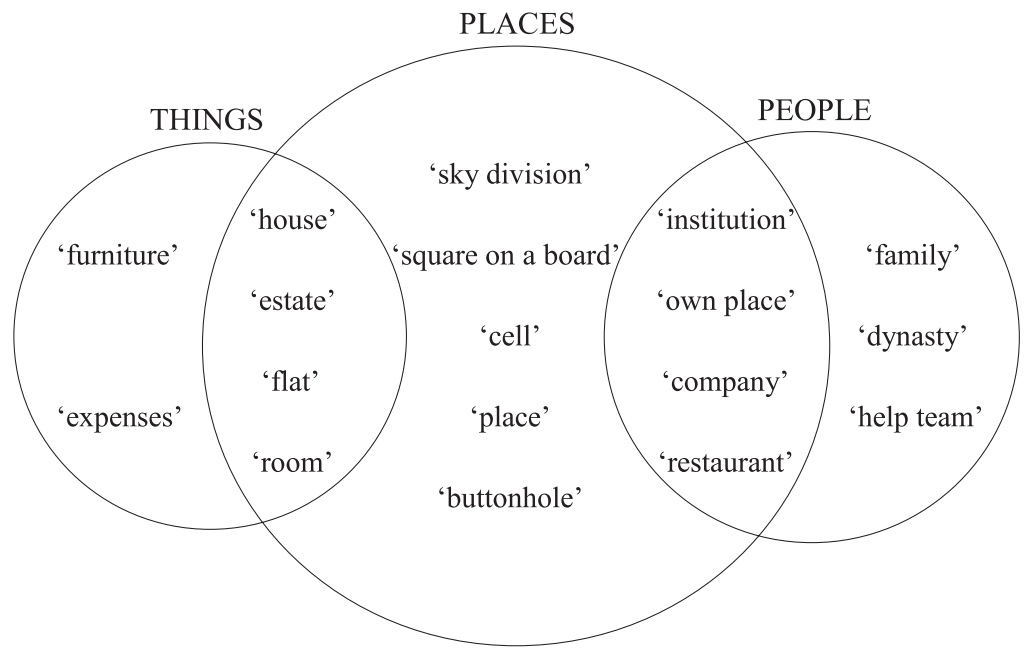

Figure 4. Genera proxima of casa

${ }^{8}$ This meaning has been suggested to me by some Portuguese native speakers who participated in X Congresso da AIL in Faro, Portugal (July 2011) and heard my talk on Portuguese home.

9 The "XVI century Polish Dictionary" also lists this meaning under the entry dom (ZaśkoZielińska 1997:45).

10 Metaphorical extensions between the categories PLACE and TIME belong to the most frequent ones in natural languages. 


\subsection{Casa as a cultural value: synonyms, idioms and proverbs}

Among the synonyms of casa, such as domicilio 'abode', habitação 'dwelling', morada 'address', moradia 'abode', residência 'residence' and vivenda 'dwelling place', maybe the most interesting one is the word lar, a close equivalent of English home. It comes from the same concept of 'hearth' as ognisko domowe in Polish, bringing into mind the connotations of food, warmth and light. The important difference between the two is that lar is used much more often in contemporary Portuguese than ognisko domowe in Polish. ${ }^{11}$ Lar, just like English home - but unlike its Polish equivalent - may refer to one's homeland, as in the sentence Esta casa é dum casal de emigrantes que regressou ao lar 'This house belongs to a couple of emigrants who came back home'. But even though it is not as archaic as ognisko domowe is in Polish, its frequency of use is much lower than that of English home. One may also refer to casa metonymically as chão'ground' ${ }^{12}$ or teto 'roof', the former picturing well the value that terra 'land' has for the Portuguese, the latter - having its counterpart in Polish dach nad glowa 'roof over one's head' - showing that casa is first of all a shelter (embora casado continua vivendo sob o teto paterno 'although married, he still lives at his father's home', Houaiss 2001). There is also a word fogo 'fire', that can be read as 'casa' (uma vila com uma centena de fogos 'a village with one hundred houses', Houaiss 2001). It is interesting, because a very similar mapping to lar >casa can be found here: once again casa is depicted as a place where warmth, light and food can be found.

Looking at the idiomatic expressions and proverbs with casa, we see again that casa is a place that should provide for its inhabitants basic needs, especially for food: Na casa em que falta o pão, todos gritam e ninguém tem razão 'In the house where there is no bread, all people shout and everybody is wrong'. Casa is also a place where one can feel $a$ vontade 'uninhibited', Em sua casa, cada um é rei 'Everybody is a king in his own house'. In Portuguese one may say em questões de números, sentia-se em casa (Malaca Casteleiro 2001), 'as far as numbers are concerned he felt really self-confident', literally 'he felt at home', where this feeling of comfort and security casa provides is extended metaphorically to the domain of knowledge. To say that someone está a entrar em casa de alguém 'is getting into someone's home' means that this person is making a joke of the other one, making fun of him. Estar de casa e pucarinho 'be with the same house and jug' refers even more to the privacy one should have at casa, meaning 'live together' (used often in the context of man and woman living together without being married).

11 In Portuguese there is also a word fogueira 'fireplace' marqued by Houaiss (2001) as an arcaic synonym of casa and lar.

12 This metonymy though is more restricted than the other two (teto and fogo). Chão seems to refer more to one's lar, lugar de origem (chão natal 'native home/land'), and can be extended to mean 'casa' in some contexts only. 
Portuguese 'home' often is depicted as having many people living together (cf. Pina Cabral 1997), the phraseological expressions such as casa de familia, or para uma casa de familia 'in great quantity' show it quite neatly. What is really important for the Portuguese casa, and absent from its Polish counterpart, is the amount of light that it must have. It should be full of light and open for the world and other people (the latter brings into mind the Polish hospitality). There are numerous proverbs that refer to that: Casa em que não entra o sol, entra o médico 'Home where the sun doesn't enter, the doctor must enter', Casa fechada, casa estragada 'Closed home, rotten home', or Em casa escura não entra alegria 'Into a dark home, joy does not enter'. And just as Polish dom 'home', casa is a source of pride and happiness for its residents: Casa própria é tesouro, não se paga nem com ouro 'One's own house is a treasure, you cannot buy it even with gold'.

\subsection{NSM definition of casa}

Let us take a look at the NSM definition of the concept casa now. The same semantic primitives used in the explication of the Polish dom are intrinsic also for casa. The definition is based on PLACE, PEOPLE, BODY, LIVE and DO that give account of the physical aspect of casa, and FEEL, THINK, WANT and GOOD that serve to picture its emotional and ideological content. But there are also differences: it seems that the domain of TIME is even more important in the case of Portuguese casa than it is in the Polish dom (see components $\mathrm{p}-\mathrm{v}$ in the definition below) and the contrast between public and private space is not as highlighted as it is in the case of Polish dom.

casa

a) a place of one kind,

b) someone can live in this place with some other people for a long time,

c) if someone lives in a place of this kind, this someone can think about this place like this:

d) when I am in this place, I can often feel something good in my body,

e) when I am in this place, nothing bad can happen to me,

f) when I am in this place, if I want to do something, I can do it,

g) this place is not like any other places,

h) I cannot feel like this in any other places,

i) when this someone thinks like this, this someone can feel something good because of this

j) if someone lives in a place of this kind with some other people, often it is like this:

k) this someone wants to do good things for these people,

l) this someone wants to be with these people in this place for some time,

m) this someone wants to do some things with these people for some time,

n) all these people are like parts of one something,

o) because of this, all these people often can feel something good, 
p) if someone doesn't live in a place of this kind for a long time, often this someone can think like this:

q) some time before, when I lived in this place, I felt something good,

r) I cannot live in this place now,

s) I can feel something bad because of it,

t) I want to do something about it,

u) I want to be in this place after some time,

v) when this someone thinks like this, often this someone can feel something good because of this,

w) it is good if someone can think like this about a place

Portuguese casa, just like Polish dom, is first and foremost 'a place of one kind' 13 (a), where people live together 'for a long time' (b). Normally, it is thought of as being a comfortable, cosy place (d) where one feels secure (e), and free from social constraints (f). It is also a special place, 'it is not like any other places' $(g-h)$. There is no casa without a family, 'people who are like parts of one something' (n). I think that being together and doing things together at home are essential features of both Polish and Portuguese family $(1-\mathrm{m})$. As is love, manifested in 'wanting to do good things for the other' $(\mathrm{k})$. Working together, talking and helping other members of the family make all the family feel 'something good' (o); it is the sense of community that is manifested in the above fragment of the definition (cf. 3.4).

The very Portuguese characteristics of feeling saudade, ${ }^{14}$ roughly 'nostalgia' for home, when one is in some other place, is manifested in often evoked memories of casa $(\mathrm{p}-\mathrm{v})$, its highly positive evaluation (q), time-oriented bitter-sweet thinking about casa as something that was but no longer is $(\mathrm{q}-\mathrm{s})$ and where one always desires to come back to $(\mathrm{t}-\mathrm{u})$. The very fact of being able to think of some place as one's casa, makes this person feel 'something good' (v). And, just as its Polish counterpart, casa is an important Portuguese value (w).

\section{Similarities between Portuguese casa and Polish dom}

When we compare the networks of meanings of the two words that depict home in Polish and in Portuguese respectively, we may see that in most cases their meanings overlap (see Fig. 1 and Fig. 3). There is only one meaning absent from

13 One may of course wonder why, after having presented such a wide array of senses casa has in Portuguese (cf. 4.1), I restrict myself to that one sense of 'place of one kind', leaving aside other important meanings such as 'family'. I must say, I am actually not very sure about positing two separate senses in this case - even though dictionaries usually do so (see Fig. 3). When we look at many contexts like volto para casa 'I come back home', onde esta a minha casa? 'where is my home?', or even escrevo para casa 'I write home' - we may see that both 'people'(i.e. family) and 'place' can substitute the word casa in the above. I think that the concept of casa combines the two domains of PEOPLE and PLACE together, PLACE being the main domain though (cf. Bartmiński 2009). It is also validated by statistics - when we look at the corpora, we may see that contexts where casa can be substituted by 'people' are really few (14 out of 200, see Bułat Silva 2014a)

14 For the analysis of the Portuguese emotion of saudade see Bułat Silva 2012c. 
Portuguese casa that Polish dom has - 'a square where a board game starts' - and, as it was said before, the number of meanings of Portuguese casa is twice as great than that of Polish dom, but most meanings - among them the meaning analysed in the present paper, 'a place where people live together' - seem to overlap.

Looking at the synonyms of both words, we notice that they highlight the very same features of home: that of being a shelter (Polish dach nad głowa, Portuguese teto 'roof'), that provides food and warmth (Polish ognisko domowe, Portuguese lar 'hearth'). The idiomatic expressions and proverbs in the two languages also seem to corroborate those essential characteristics of casa and dom (see 3.3 and 4.3). In the above data another feature is well visible in the two: it is the feature of casa/dom being 'one's own private place', where one can do what he wants to do (Polish Wolnoć Tomku w swoim domku, Portuguese Em sua casa, cada um é rei).

There is also a bunch of literal equivalents of collocations involving the words casa and dom (see Table 2). Both in Portuguese and in Polish, we have such phrases as przyjaciel domu, amigo da casa 'someone who is close to the family', or czuć sie jak u siebie w domu, sentir-se em casa 'to feel comfortable and free'. There are many equivalent institutional names that involve dom and casa, namely Dom Boży, casa de Deus meaning 'temple'; dom poprawczy, casa de corecção, 'reformatory'; dom handlowy, casa comercial 'shopping centre'. Both in Polish and in Portuguese football players can talk about grać w domu, jogar em casa, meaning playing at their own playground.

Table 2: Literal equivalents of collocations with dom and casa

\begin{tabular}{|c|c|}
\hline In Polish & In Portuguese \\
\hline pani domu & dona de casa \\
\hline przyjaciel domu & amigo da casa \\
\hline petnić honory domu & fazer as honras da casa \\
\hline Dom Boży & casa de Deus \\
\hline dom opieki & casa de repouso \\
\hline dom poprawczy & casa de correcção \\
\hline dom wariatów & casa de orates \\
\hline dom bankowy & casa bancária \\
\hline dom handlowy & casa comercial \\
\hline dom pogrzebowy & casa funerária \\
\hline grać $w$ domu & jogar em casa \\
\hline czuć się jak u siebie $w$ domu & sentir-se em casa \\
\hline
\end{tabular}

Neither for Polish nor for Portuguese dom as 'ojczyzna', and casa as 'terra' ('homeland') are common meanings (cf. Bartmiński 2009). They belong rather to a literary register. 


\section{Conclusions}

I entirely agree with Bartmiński (2009:150) when he states that one of the most important features of Polish dom is its multidimensionality. And I am sure that it holds also for the Portuguese casa. All the three dimensions described by Bartmiński are as important for the linguistic view of casa as they are for the linguistic image of dom. But, in my opinion, one essential dimension is missing both from the dictionary definitions and Bartmiński's description. It is the emotional dimension of dom and of casa. The role of home in shaping people's characters and their emotional responses to what life brings them is crucial. Dom is strongly related to the emotions of love, miłość, fondness, czułość, homesickness, tęsknota, to the feelings of security, bezpieczeństwo, confidence, zaufanie, and warmth, ciepło (Zaśko-Zielińska 1997, Żywicka 2006, Dobraczyński 2011, Gołębiewski 2011). Casa refers to amor 'love', ternura 'tenderness', saudade 'nostalgia', and to segurança 'security', confiança 'trust', and calor 'warmth' (Klimt 1989, Pina Cabral 1997).

Contrary to what some researchers say when they describe domicide, a deliberate 'killing' of home in modern societies (Porteous and Smith, 2001, quoted in Brydon 2007), it seems that neither in Poland nor in Portugal home is endangered socially - in both countries home and family are important values, on which cultural identity is built. ${ }^{15}$ Both Polish and Portuguese homes are closely related to the family, perceived as a network of intergenerational relationships and responsibilities. They are both more demanding towards its members than for example English or Australian homes. In Polish dom, all family members have many responsibilities and duties, especially moral ones (cf. Polish cultural scripts of sincerity and emotional warmth, see also Besemeres 2007 on emotional blackmail). A person is expected to 'feel something good and do something good for other people living in the same place', even if he does not feel the need to do so. Same for the Portuguese casa, based on a script of helping family members (see Pina Cabral 1997). Anglo home, with its script of personal autonomy, puts less pressure on its members and generates, seemingly, less stressful situations.

The most important difference between the Polish and the Portuguese lies in the treatment of public space. For the Polish, home is definitely their destination point, a safe place, where they can be themselves. Public space is perceived as quite hostile in Poland: people barely smile, and are not very nice towards each other (cf. Klos Sokol 1994:44). Dom, however, should be open and friendly towards other people, hospitality is still a great cultural value in Poland (see the last part of the definition, lines $\mathrm{p}-\mathrm{t}$ ). In Portugal people meet more in restaurants, cafes or bars. Public space seems safer and friendlier. The other difference is the

15 Nevertheless, the image of dom as a 'stronghold of national identity' (Bartmiński 2009:149) is much more blurred than it was thirty years ago. 
social (and spatial) meaning Portuguese attach to their home (see Klimt 1989). They sometimes go as far as having a house in Portugal that they almost never use - because of living abroad - an idea which would never occur to Polish people. That shows that the Portuguese are more strongly attached to their terra 'land', and think more about casa they left behind (hence the element of thinking about returning home in the definition of casa).

I consider both casa and dom important semantic molecules on which many other meanings, like these of 'hospitality', 'belonging' or 'homeland', are built (see also Rapoport 1969). If we have different 'homes', than our sense of belonging, what we feel for our homeland, or how we treat our guests will simply differ. If our names for 'home' are different in meaning, than the other concepts vary accordingly (a good example is Klos Sokol 1994:77-79 on Polish hospitality). Hence, it is important to investigate the notion of 'home' and see what exactly it means in different languages and cultures. That can save us from many cross-cultural misunderstandings.

\section{References}

APRESJAN Jurij, 1994, Naiwny obraz świata a leksykografia, in: Etnolingwistyka 6, pp. 5 - 12.

BARTMIŃSKI Jerzy, 2009, Aspects of Cognitive Ethnolinguistics, London.

BAUMAN Zygmunt, 2011, Kultura w płynnej nowoczesności, Warszawa.

BESEMERES Mary, 2007, Between żal and emotional blackmail: Ways of being in Polish and English, in: Besemeres M./Wierzbicka A. (eds.), Translating Lives: Living with Two Languages and Cultures, St. Lucia, pp. $128-138$.

BRYDON Diana, 2007, Canadian writers negotiating home within global imaginaries, Adelaide.

BuŁat Silva Zuzanna, 2012a, O conceito de 'casa' em português europeu, in: Petrov P./Quintion de Sousa P./López-Iglésias Samartim R.E./Torres Feijó E.J. (eds.), Avanços em Ciências da Linguagem, Santiago de Compostela-Faro, pp. $343-357$.

BuŁat Silva Zuzanna, 2012b, Portugalski DOM - uma casa portuguesa, in: Abramowicz M./ Bartmiński J./Bielińska-Gardziel I. (eds.), Wartości w językowo-kulturowym obrazie świata Słowian i ich sąsiadów 1, Lublin, pp. $123-135$.

BuŁAT Silva Zuzanna, 2012c, Saudade: A Key Portuguese Emotion, in: Emotion Review 4/2, pp. $203-211$.

BuŁAT SiLVA Zuzanna, 2014a, Portugalski DOM - badanie korpusowe, in: Bartmiński J./BielińskaGardziel I./Niebrzegowska-Bartmińska S. (eds.), Wartości w językowo-kulturowym obrazie świata Słowian i ich sąsiadów 2. Wokół europejskiej aksjosfery, Lublin, pp. 41-52.

BUŁAT SiLva Zuzanna, 2014b, Jaki obraz DOMU mają młodzi Portugalczycy? Badanie ankie-towe, in: Bielińska-Gardziel I./Niebrzegowska-Bartmińska S./Szadura J. (eds.), Wartości w językowokulturowym obrazie świata Słowian i ich sąsiadów 3. Problemy eksplikowania i profilowania pojęć, Lublin, pp. 309-322.

BuŁAT SILVA Zuzanna, 2015, CASA - portugalski dom, in: Bartmiński J./Bielińska-Gardziel I./ Żywicka B. (eds.), Leksykon aksjologiczny Słowian i ich sąsiadów, Lublin, pp. $401-431$.

BuŁAT SiLva Zuzanna / STĘPIEŃ Maciej Adam, 2014, La imagen lingüística de CASA en español y portugués, in: Bułat Silva Z./Głowicka M./Wesoła J. (eds.), Variación, contraste, circulación. Perspectivas lingüísticas en el hispanismo actual, Wrocław, pp. 97-108. 
DOBRACZYŃSKI Bartłomiej, 2011, Wstęp do katalogu wystawy fotografii Andrzeja Kramarza i Weroniki Lodzinskiej-Dudy, Wrocław.

DUBISZ Stanisław, 2006, Uniwersalny słownik języka polskiego PWN, Warszawa.

GODDARD Cliff / WiERZBICKA Anna (eds.), 2002, Meaning and Universal Grammar. Theory and Empirical Findings, Amsterdam/Philadelphia.

GoDDARD Cliff / WIERZBICKA Anna, 2014, Words and Meanings: Lexical Semantics Across Domains, Languages, and Cultures, Oxford.

GoŁĘBIEWSKI Marian, 2011, List pasterski na Adwent, Wrocław.

GURNEY Craig M., 1997, “... half of me was satisfied”: making sense of home through episodic ethnographies, in: Women's Studies International Forum 20, pp. $373-386$.

HouAiss Antônio / SALLES Vilar Mauro de / Mello Franco Francisco Manoel de, 2001, Dicionário Houaiss da Língua Portuguesa, Rio de Janeiro.

KLIMT Andrea, 1989, Returning ,home”: Portuguese migrants' notions of temporariness, permanence and commitment, in: New German Critique, pp. 47-70.

KLOS SOKOL Laura, 1994, Polsko-amerykańskie qui pro quo, Warszawa.

MAĆKIEWICZ Jolanta, 1997, Wszędzie dobrze, ale w domu najlepiej (There is no place like home), czyli dom we frazeologii polskiej i angielskiej, in: Sawicka G. (ed.), Dom w języku i kulturze, Szczecin, pp. $69-75$.

MalaCa CASTEleiro João, 2001, Dicionário da Língua Portuguesa Contemporânea, Lisboa.

PINA CABRAL João, 1997, Houses and legends: family as community of practice in urban Portugal, in: Gullestad M./Segalen M. (eds.), Family and kinship in Europe, London, pp. 77-102.

RAPOPORT Amos, 1969, House form and culture, Englewood Cliffs.

WiERZBICKA Anna, 1996, Semantics: Primes and Universals, Oxford.

WiERZBICKA Anna, 2009, Reciprocity. An NSM approach to linguistic typology and social universals, in: Studies in Language 33, pp. $103-174$.

WierzBICKA Anna, 2016, Terms of Address as Keys to Culture and Society: German Herr vs. Polish Pan, in: Acta Philologica 49, pp. $29-44$.

ZAŚKO-ZIELIŃSKA Monika, 1997, Dom w polszczyźnie iinnychjęzykach słowiańskich, in: Sawicka G. (ed.), Dom w języku i kulturze, Szczecin, pp. $43-52$.

ŻYwiCKA Beata, 2006, Dom, in: Bartmiński J. (ed.), Język - wartości - polityka, Lublin, pp. 163 - 167. 